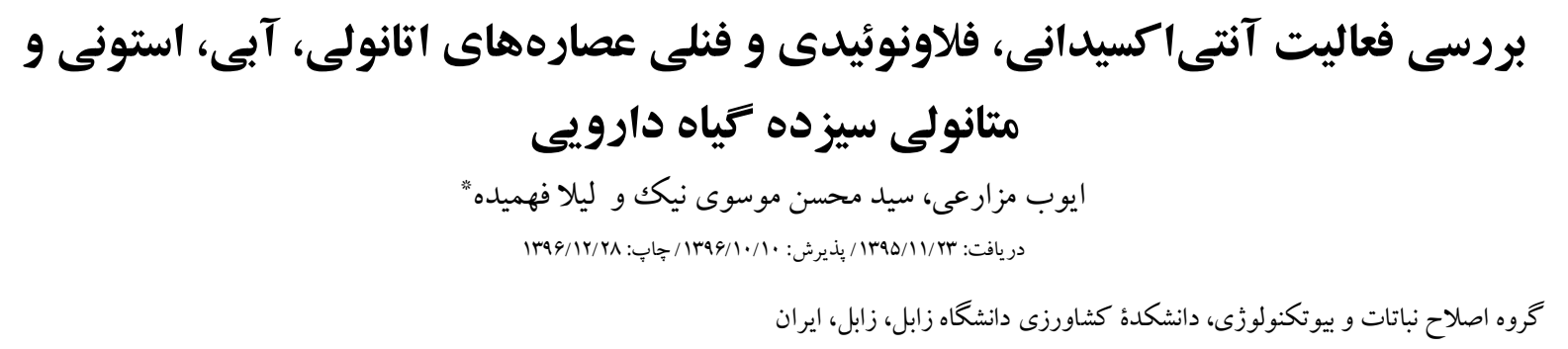

1.fahmideh@uoz.ac.ir : مسئول مكاتبات

جكيده. تر كيبات فنوليك، بهويزه آنهايى كه منشأ كياهى دارند بهدليل ويزگگهاى آنتىاكسيدانى، بخش اساسى رزيم غذايى انسان را تشكيل مىدهند.

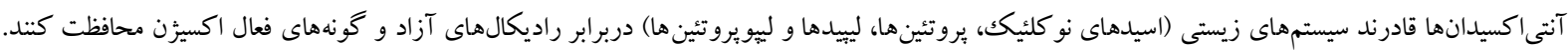

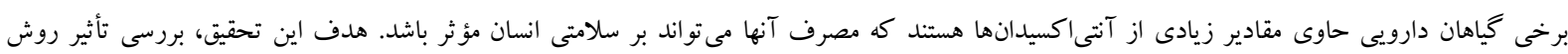

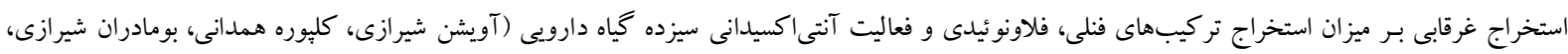

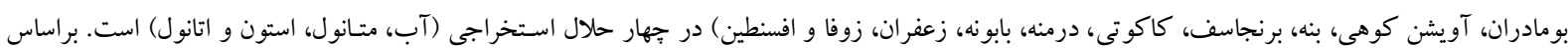

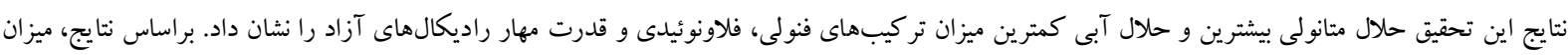

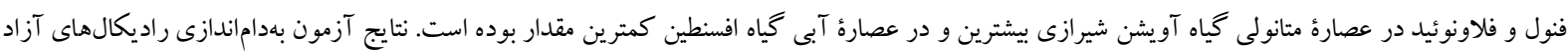

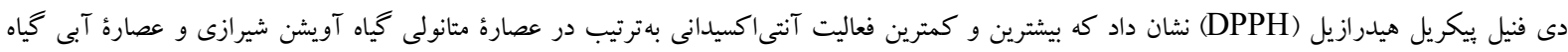

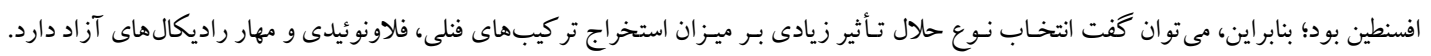

وازههاى كليدى. آويشن شيرازى، استخراج غرقابى، افسنطين، راديكالهاى آزاد

\title{
Assessments of phenolic, flavonoid and antioxidant activity of aqueous, alcoholic, methanol and acetone extracts of thirteen medicinal plants
}

\author{
Ayoub Mazarie, Seyed Mohsen Mousavi-Nik \& Leila Fahmideh* \\ Received 11.02.2017/ Accepted 31.12.2017/ Published 19.03.2018
}

Department of Plant Breeding and Biotechnology, Agriculture Faculty, University of Zabol, Zabol, Iran

*Correspondent author: 1.fahmideh@uoz.ac.ir

\begin{abstract}
Phenolic compounds, especially those with plant origin, constitute an essential part of the human diet due to their antioxidant properties. Antioxidants protect biological systems (nucleic acids, proteins, lipids, lipoproteins) against free radicals and reactive oxygen species. Some medicinal plants contain so high amounts of antioxidants that their use can be considerably effective for human health. The aim of this study was to evaluate the effect of flooding extraction method on phenolic compounds, flavonoids and the level of free radical scavenging properties of medicinal plants including Thyme, Hamadani Yarrow, Shirazi mountain thyme, Yarrow, Chamomile, Saffron corm hyssop Sagebrush, wormwood, Artemisia and Ziziphora clinopodioiedes, in four extraction solvents including water, methanol, acetone and ethanol. The results showed that methanol and water solvents had the highest and the lowest total phenolic, flavonoid and antioxidant activity, respectively. The results also showed that methanol extraction of Shirazi thyme and water extraction of Wormwood plant had the highest and the lowest phenol and flavonoids contents, respectively. The results of trapping the free radicals of DPPH indicated that the methanol extract of Shirazi thyme and aqueous extract of wormwood had the highest and the lowest inhibition activities, respectively. Therefore, the selection of solvent type can affect the rate of the extraction of phenolic compounds, flavonoids and antioxidant activity.
\end{abstract}

Keywords Artemisia absinthium, flooding extraction, free radicals, Zataria multiflora 


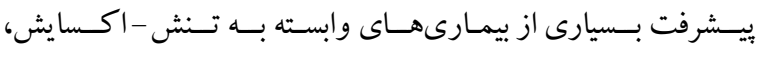

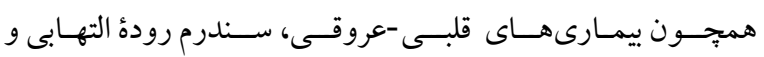
بيمارى آلزايمر است (Ahmadi et al., 2007).

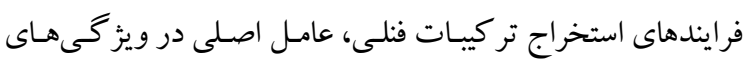

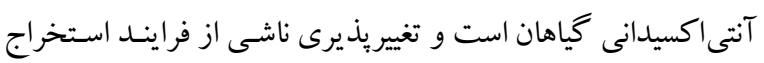

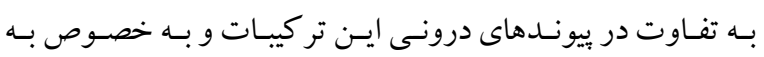

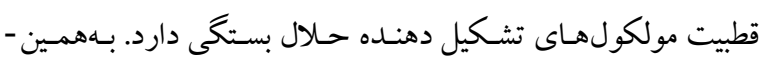

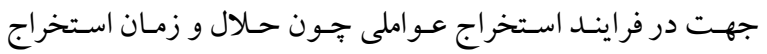
بسيار مهـم هسـتند (Hayouni et al., 2007)، امـا دمـا، قـدرت استخراج كند كَى حلال، زمان و روش استفادهشـهـ بـراى استخراج

عصاره را بسيار تحت تاثير قرار مىدهند (Betancourt, 2008).

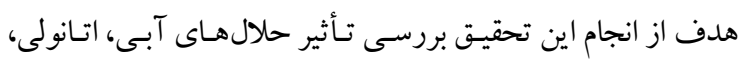

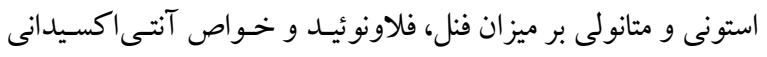

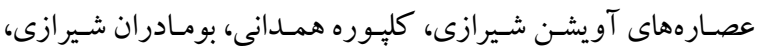

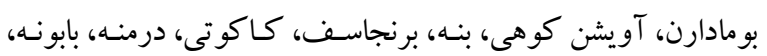
زعفران، زوفا و افسنطين در محيط آزمايشگاهى است.

\section{مواد و روش ها}

در اين مطالعه نمونـهـاى گياهى مـورد نظـر (جـدول ) ) از مناطق

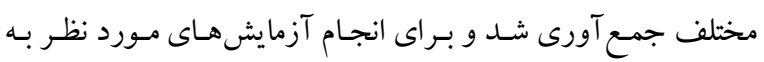

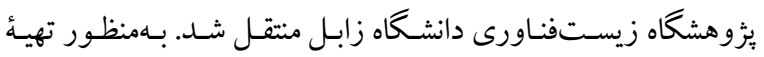

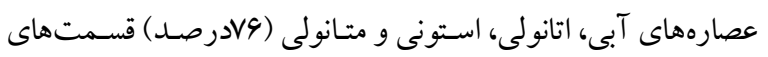

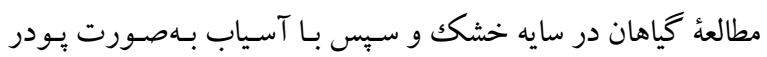

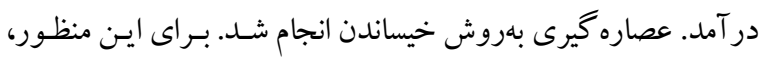

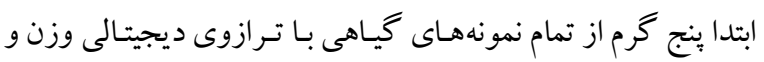

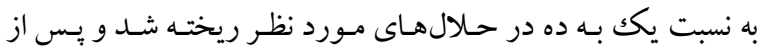

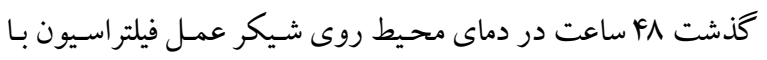

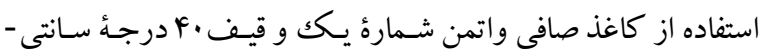

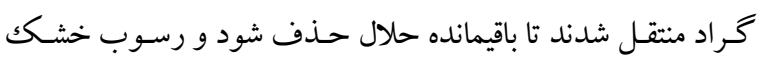

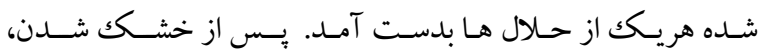

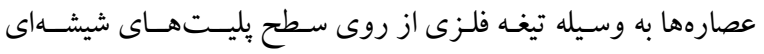

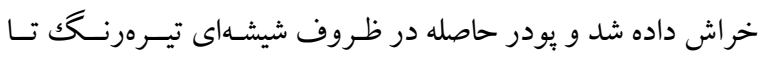

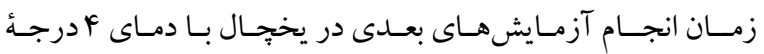

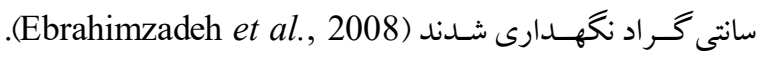
تعيين ميزان فنل كل: مقـادير فنـل كل بـا روش فولين سيو كالتيو
مقدمه

تركيبـات فنلـى بــه فنـل هــاى سـاده، اســيدهاى فنلـى، مشـتقات

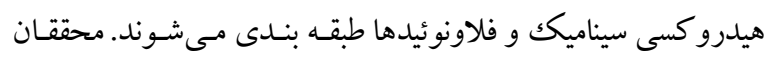
عملكرد بسيارى از تر كيبات فنلى بـهمنزلـهُ تر كيبـات آنتى اكسيديدان

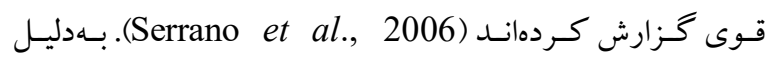

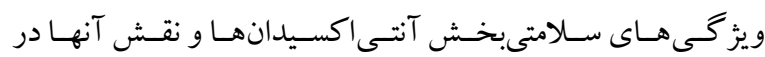

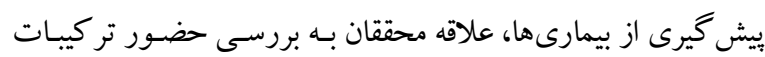

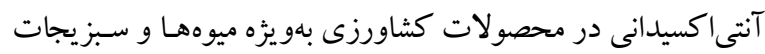

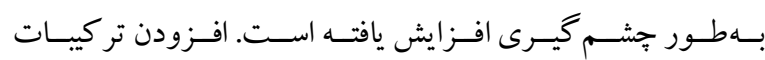

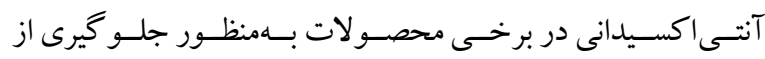

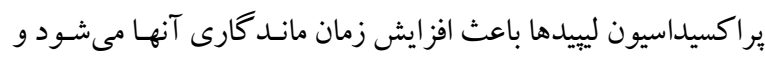

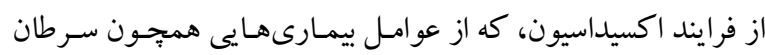

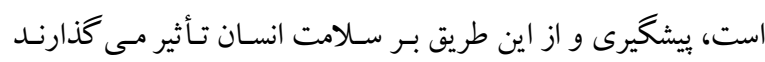
.(Shi et al., 2005)

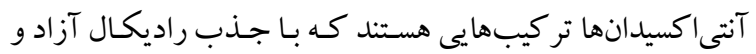

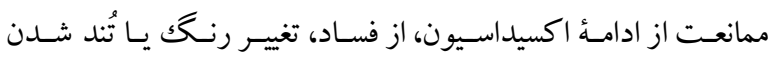

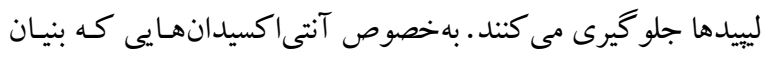

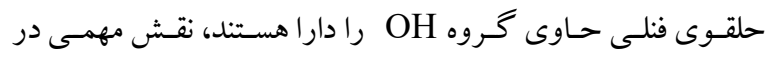

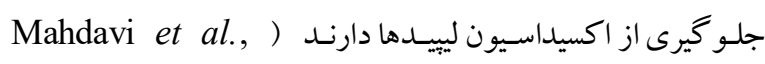

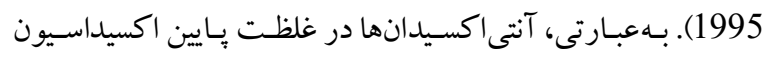

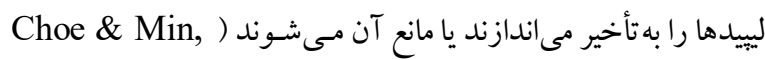
مص ف 2009; Kamkar et al., 2010 مصرف آنتى اكسيدانهاى سنتزى كزارش شده اسـت، بـهورى كـهـ

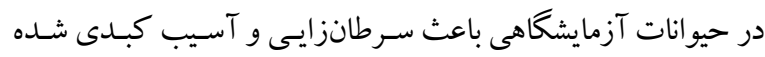

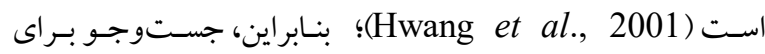

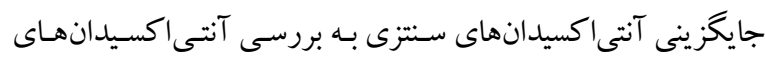

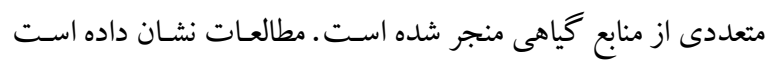

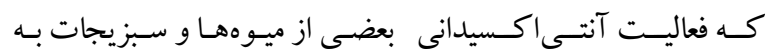

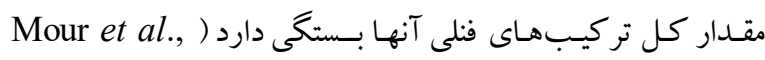

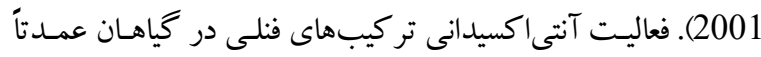

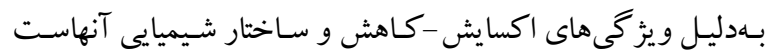

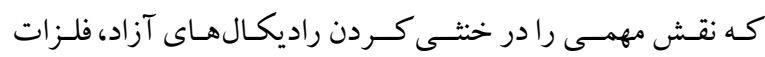

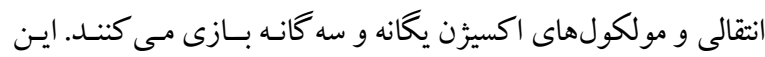

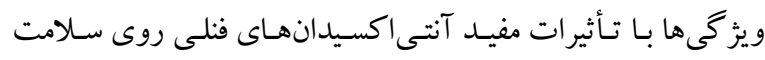

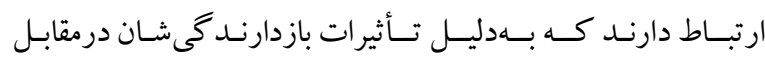


جدول 1- اسامى گياهان مورد استفاده.

Table 1. List of the used plants.

\begin{tabular}{|c|c|c|c|c|c|}
\hline $\begin{array}{c}\text { منطقه جمع آورى } \\
\text { the region gather }\end{array}$ & $\begin{array}{c}\text { نام علمى } \\
\text { scientific name }\end{array}$ & $\begin{array}{c}\text { تيره } \\
\text { Family }\end{array}$ & قست مورد استفاده & $\begin{array}{c}\text { نام فارسى } \\
\text { Persian name }\end{array}$ & $\begin{array}{l}\text { رديف } \\
\text { Row }\end{array}$ \\
\hline خراسان جنوبى - قاين & Artemisia absinthium $\mathrm{L}$. & Asteraceae & بركى، سرشاخه هاى كلدار & افسنطين & 1 \\
\hline فارس - فراشبند & Zataria multiflora Boiss. & Lamiaceae & 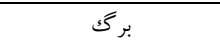 & اويشن شيرازى & $r$ \\
\hline سيستان و بلوحستان- سراوان & Thymus vulgaris $\mathrm{L}$. & Lamiaceae & 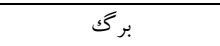 & اويشن كوهى & $r$ \\
\hline خراسان جنوبى - قاين & Matricaria chamomilla $\mathrm{L}$. & Asteraceae & كل & بابونه & F \\
\hline سيستان و بلوحستان- سراوان & Artemisia vulgaris L. & Asteraceae & اندم هاى هوايى & برنجاسف & $\Delta$ \\
\hline كرمان- جيرفت & Pistacia atlantica Desf. & Anacardiaceae & ميوه & بنه & 4 \\
\hline خراسان جنوبى - قاين & Achillea wilhelmsii C. Koch & Asteraceae & سرشاخه هاى گل دار & 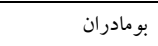 & 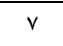 \\
\hline فارس- فراشبند & Achillea eriophora Boiss. & Asteraceae & سرشاخه هاى گل دار & بومادران شيرازى & $\wedge$ \\
\hline سيستان و بلوجستان- سراوان & Artemisia aucheri $\mathrm{L}$. & Asteraceae & سرشاخه هاى بر كُ دار & 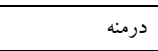 & 9 \\
\hline خراسان رضوى- گتاباد & Crocus sativus $\mathrm{L}$. & Iridaceae & 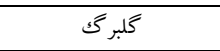 & زعفران & 1. \\
\hline خراسان جنوبى - قاين & Hyssopus Officinalis L. & Lamiaceae & بركى، سرشاخه هاى كلدار & 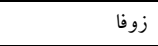 & 11 \\
\hline خراسان رضوى- كاشمر & Ziziphora clinopodioids Lam. & Lamiaceae & برگك و شاخه & كاكوتى & ir \\
\hline فارس-فراشبند & Teucrium polium $\mathrm{L}$. & Lamiaceae & برگك & كليو ره همدانى & ir \\
\hline
\end{tabular}

ارزيـابى فعاليـت آنتـى اكسـيدانى: بو Y-دى فنيـل - - بيكريـل

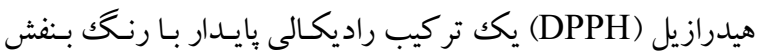

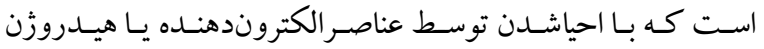
(تركيبات آنتى اكسيدانى) به دى فنيل بيكـرين هيـدرازيل زرد رنـگ

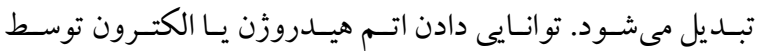
تر كيبات و عصارههاى مختلـف در ايسن آزمـون بـا ميززان بـىرنـك كـردن يـا كـاهش ميـزان جـــب نـورى محلـول بـنفش DPPH در متانول سنجيده مىشـود. بـدين ترتيـب كـه •هميكروليتـر از عصـاره،

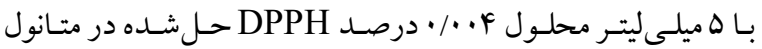

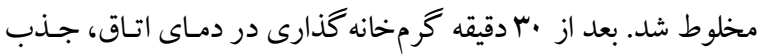
نورى نمونهها در طول مـوج اه نـانومتر قرائـت شـد. درصـد مهار راديكالهاى آزاد DPPH با استفاده از فرمول ذيل محاسبه شد. Sc $(\%)=[(\mathrm{A} 0-\mathrm{As}) / \mathrm{A} 0] \times 100$

$$
\begin{aligned}
& \text { A0=A0 }
\end{aligned}
$$

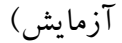

$$
\begin{aligned}
& \text { As }
\end{aligned}
$$

م درصد مهار راديكال آزاد (Burits \& Bucar, 2000) تجزيه و تحليل آمارى: اين آزمايش بهصورت فاكتوريل درقالب طرح كاملاً تصادفى با سه تكرار انجام شد. فاكتورهاى اين آزمايش شامل تعداد گياه (سا سطح) و انواع حلال (F سطح) بودند. پِ از اندازه گيرى تركيبات فنلى كل، ميزان بهداماندازى راديكالهاى آزاد و ميزان تركيبات فلاونوئيدى كل، تجزئ
اندازهگيرى شد (Ordone, et al., 2008). عصاره با غلظت ابه

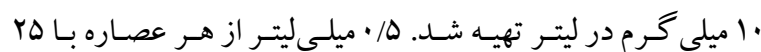
ميلىليتر واكنشخر r/ • نرمال فـولين سـيو كالتيو مخلـوط و بـهمـدت هـ ه

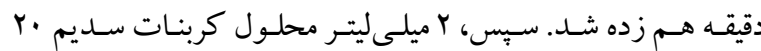

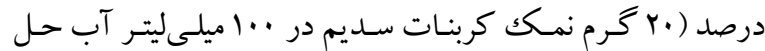
شد تا محلول • بدرصد كربنات سديم تهيه شود) اضـافه شـد. جـــب نمونهها بِ از Y ساعت قر اردادن نمونههـا در دمـاى اتـاق بـا دسـتخاه اسبكتروفتومتر با طول موج •V9نـانومتر در مقابـل بلانـك (متـانولى،

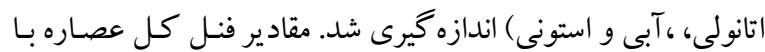
استفاده از منحنى استاندارد بر اساس ميلى گرم گاليكك اسيد در گرم عصاره اندازهكيرى شد.

تعيين محتــواى فلاونوئيــى عصـاره: ميـزان محتـواى فلاونوئيسـا عصاره با روش رنگكسنجى ارزيـابى شـد (Chang et al., 2002). عصاره با غلظت mg/ml · ا تهيـه شـد. ه/ • ميلىليتـر از عصـاره در

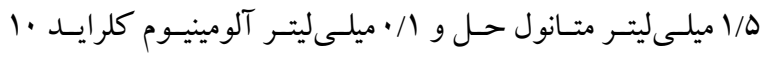
درصد به آن اضافه شد. سبس، / / ميلى ليتـر محلـول پِتاسـيم اسـتات

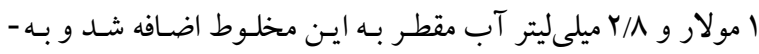
مدت .ب دقيقه در دماى اتاق نكهدارى شـد . جـذب مخلـوط حاصـل

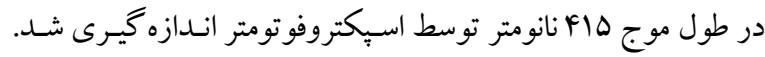
ميـز ان فلاونوئيـــ بـا اسـتفاده از منحنى اسـتاندارد بر اسـاس ميلى كـرم كوئرستين در زرم عصاره گزارش شدان 
تركيبات فلاونوئيدى: اثـر نـوع حـلال بهكـاررفته در استخراج تركيـبهـاى فلاونوئيـدى در سـطح احتمال يكك درصد مؤثر و معنى دار بـود، بـهـورىكـه حلال متانولى با ميزان استخراج

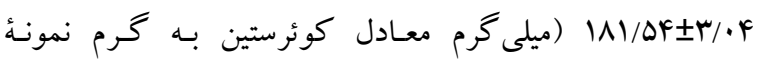

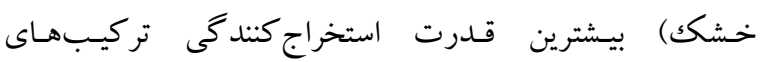
فلاونوئيدى را نسبت بـه بقئُ حلالها داشته است. همجنين، كمتـرين قـدرت استتخراج مربـوط بـه استفاده از آب با ميزان

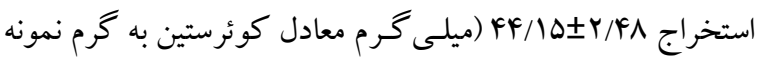
خشك ) بـراى استتخر اج اين دسته از تر كيب ها بوده است (شكل a

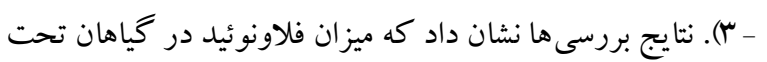

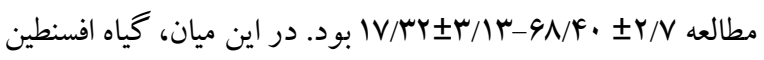
كمترين و كياه آويشن شيرازى (Artemisia absinthium)

(Zataria multiflora) اثر متقابل حلال و كياه برميزان استخراج فلاونوئيــ كل در شـكل F آمده است. عصارة آبى كياه Artemisia absinthium بـه ترتيـب

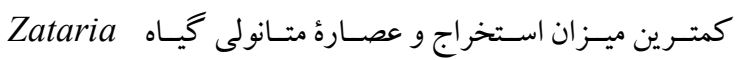
multiflora بررسى شده داشتند. ميزان فعاليت آنتىاكسيدانى: نتايج مقايسة ميـانخين ميـزان فعاليـت آنتى اكسيدانى حلالهاى مختلف نشان داد كه نوع حلال بـه كاررفتـه تأثير معنى دارى بر ميز ان فعاليت آنتى اكسـيدانى عصـارههـاى گياهـان مختلف داشت. در شكل و 9 اثر متقابـل نـوع حـلال و گيـاه نشـان داده شــده اسـت. حسلال آبــى گيـاه افسـنطين كمتـرين ميـز ان فعاليـت آنتى اكسيدانى و تيمارمتانولى گيـاه آويشـن شـيرازى بيشـترين ميـزان فعاليت را نسبت به سـاير گياهان تحـت بررسى داشـتند. عصـارههـاى كياهـان مختلـف داشـت. در حلالهــاى مـورد بررسـى، بيشـترين و كمتـرين ميـزان فعاليـت آنتى اكسـيدانى بـه ترتيـب مربـوط بـه حـلال

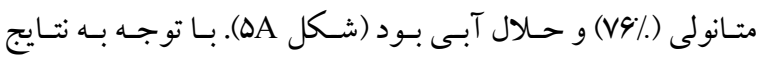
مقايسه ميانكين فعاليـت آنتى اكسيدانى شـكل هB مشــص شـد كـه گياه افسـطين (Artemisia absinthium) كمتـرين ميسزان و كيـاه آويشـن شـيرازى (Zataria multiflora) بيشـترين ميززان بـهدام اندازى راديكالهاى آزاد رادارا بودند.

گياهان تركيبات متعددى دارند كه ساختارهاى گوناگونى را
واريانس و مقايسٔ ميانگين (با روش دانكن) با استفاده از نرمافزارهاى EXCEL و 9.1 SAS انجام شد.

نتايج

براساس نتايج تجزية واريـانس اثـر نـوع حـلال، كيـاه و اثـر متقابـل حلال در كياه براى مقدار كل تر كيبات فنلى، فلاونوئيسد كل و مهـار

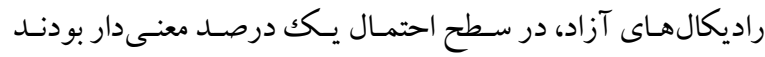

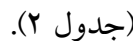

نتايج مقايسه ميانكين

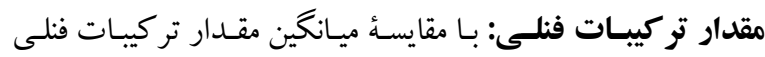
عصارههاى حاصل از حلالهـاى مختلـف، بيشـترين مقـدار تر كيبـات فنلـى بــه ترتيـب در عصـارههـاى متـانولى (V9 درصــ) و كمتـرين در حلال آبى مشـاهده شـد (شـكل A (1). نتايج مقايسـة ميـانكين مقـدار IB تر كيبات فنلى عصارههـاى حاصل از گياهـان مختلـف در شـل نشـان مسىدهـد كـه نـوع گيـاه اسـتفاده شـــ. جهـت اسـتخر اج تـأثير معنى دارى (در سطح يكك درصـد) برمقـدار تر كيبـات فنلى دارد. در بين كياهان بررسى شده، بيشترين مقدار تر كيبـات فنلى بـه ترتيـب در

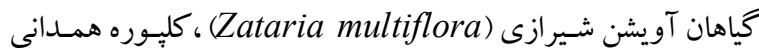

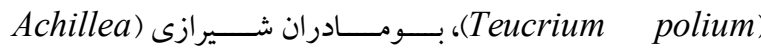
(eriophora )، بومادارن (Achillea wilhelmsii)، آويشن كـوهى (Thymus vulgaris) Ziziphora clinopo-(Artemisia vulgaris)

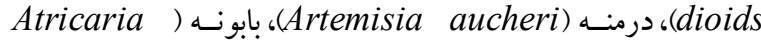
Hyssopus (Chamomilla )، زعفران (Crocus sativus)، زوفـا (Chas (officinalis آمــد و تر كيبـات فنلـى از ايـن نظـــ اخـتلاف معنسىدارى داشـتند. بيشترين و كمترين مقـدار تر كيبـات فنلـى بـهـترتيـب مربـوط بـهـ گيـاه آويشن شيرازى و افسنطين بود. در بررسى اثر متقابل حسلال و گيـاه (شـكل Y)، تيمـار متـانولى گيـاه

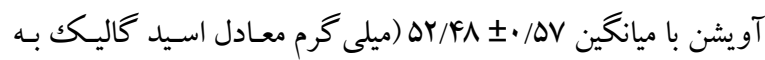

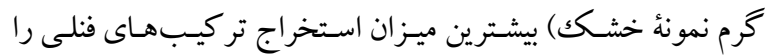
داشت و كمترين ميزان استخر اج تركيبات فنلـى نيـز بـه تيمـار حهلال

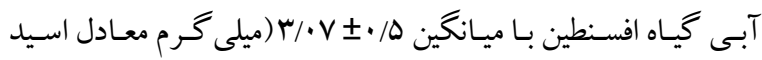
كاليك به كرم نمونهُ خشكى) مربوط بود. 
جدول r- تجزيه واريانس مقدار فنل كل، فلاونوئيد و مهار راديكال هاى آزاد.

Table 2. Analysis of variance of total phenolics, flavonoids and free radical scavenging.

\begin{tabular}{|c|c|c|c|c|}
\hline DPPH & فلاونوئيد & فنل كل & درجه آزادى & منابع تغيير \\
\hline YAYDG/9 & IMFFAY/9** & 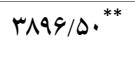 & $r$ & حلال \\
\hline$F A F / M F$ & $1949 \cdot 19^{* * * *}$ & $F V F / q^{* * *}$ & ir & كياه \\
\hline $1 \cdot / 9 \cdot * * *$ & $\Delta I V N Y^{* * *}$ & $G F / Y I: *$ & ra & حلال * Fياه \\
\hline $1 / 91$ & $1 / V$ & $\cdot / \mu$ & 1.4 & خطا \\
\hline$\cdot / 9 V$ & $\cdot / 91$ &.$/ 99$ & & ضريب تبيين \\
\hline$r / \Delta$. & $r / \Delta$. & $r / \Lambda \Lambda$ & & ضريب تغييرات \\
\hline
\end{tabular}

* و ** به ترتيب معنى دار در سطح احتمال يك و ينج درصد و ns در سطح ينج درصد معنى دار نيست.

$*$ and ** are significantly different in $5 \%$ and $1 \%$ respectively, and ns is not significantly different.

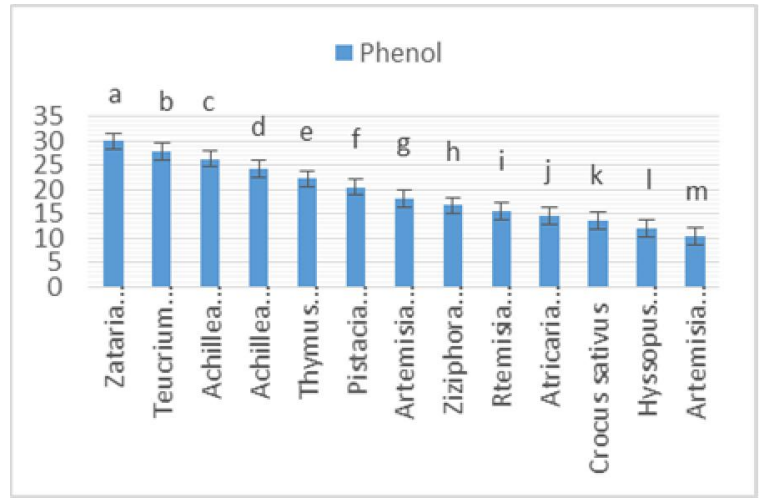

B

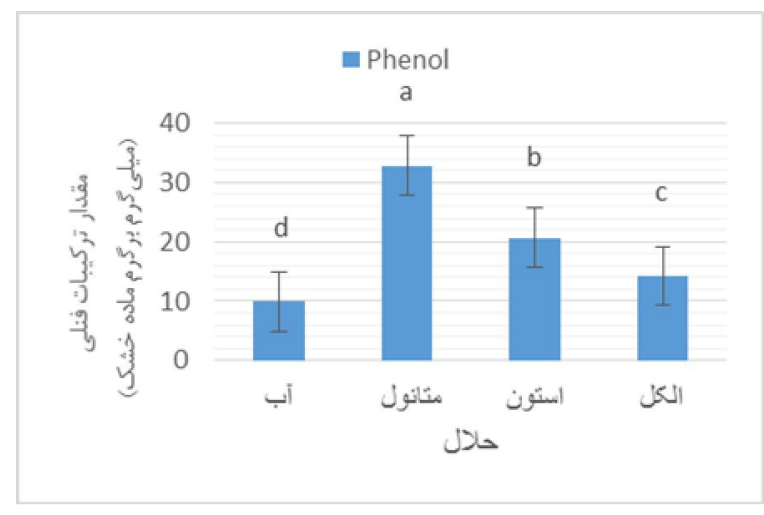

$\mathbf{A}$

شكل ا - A تغييرات مقدار تر كيبات فنلى كل حاصل از حلالهاى مختلف، B: تغييرات مقدار تر كيبات فنلى كل حاصل از گياهان.

Fig. 1. A: Changes the amount of total phenolic compounds derived from various solvents, B: Change the value of total phenolic compounds derived from plants.

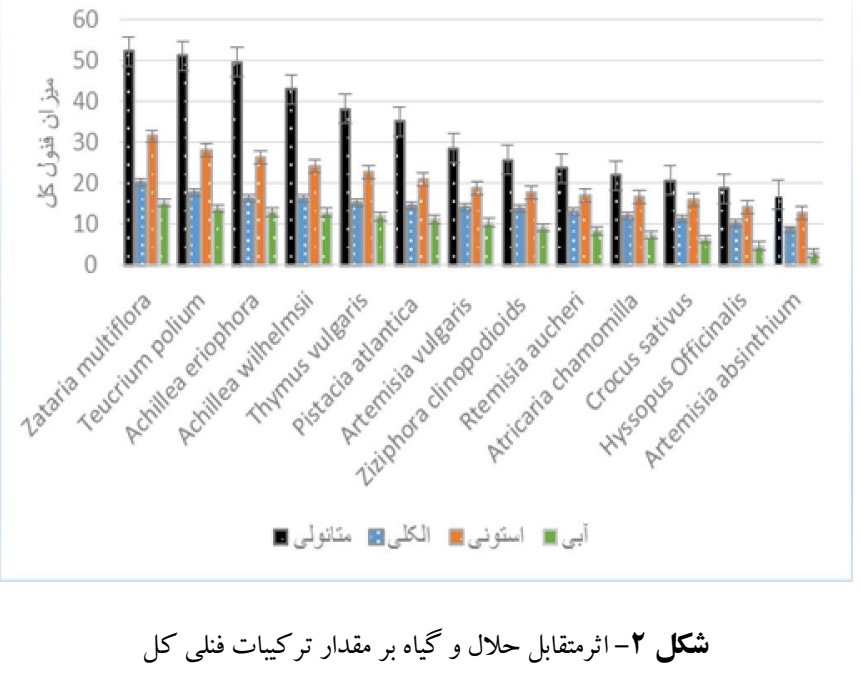

Fig. 2. Effect of interaction of solvent and plant on total phenolic compounds 


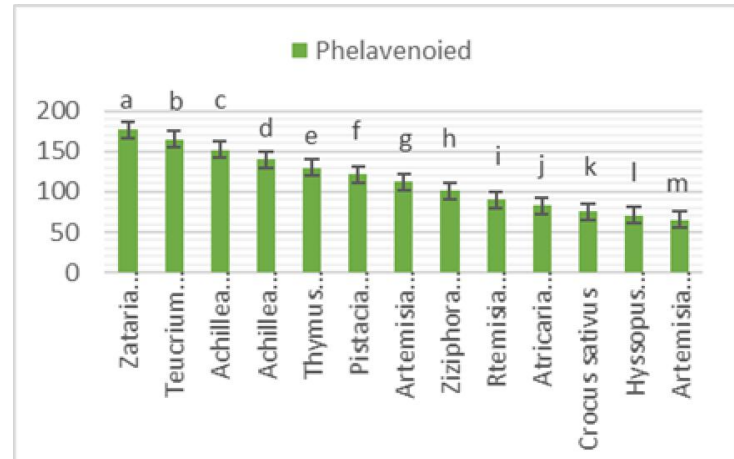

B

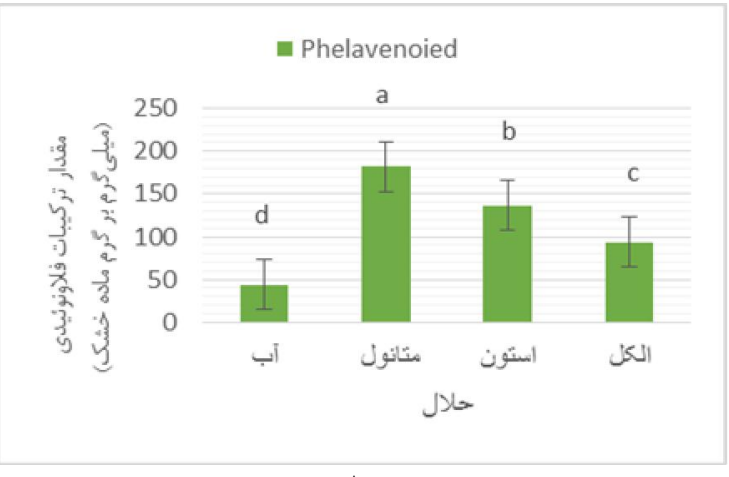

A

شكل r- A A تغييرات مقدار تر كيبات فلاونوئيدى كل حاصل از حلال هاى مختلف، B: تغييرات مقدار تركيبات فلاونوئيدى كل حاصل از گياهان.

Fig. 3. A: Changes of the amount of total flavonoid compounds obtained from different solvents, B: The changes in the value of total flavonoid compounds derived from plants.

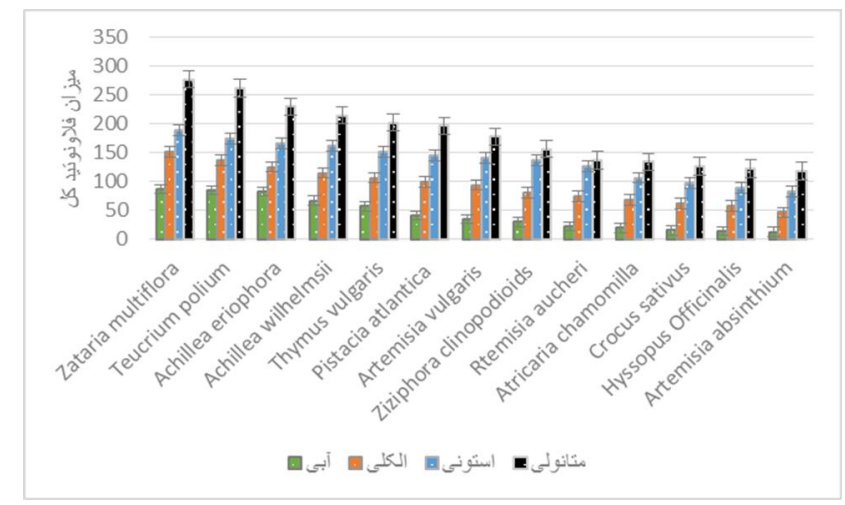

شكل ع- اثر متقابل گياه و نوع حلال بر مقدار تركيبات فلاونوئيدى كل.

Fig. 4. Effect of interaction of solvent and plant on total flavonoid compounds.

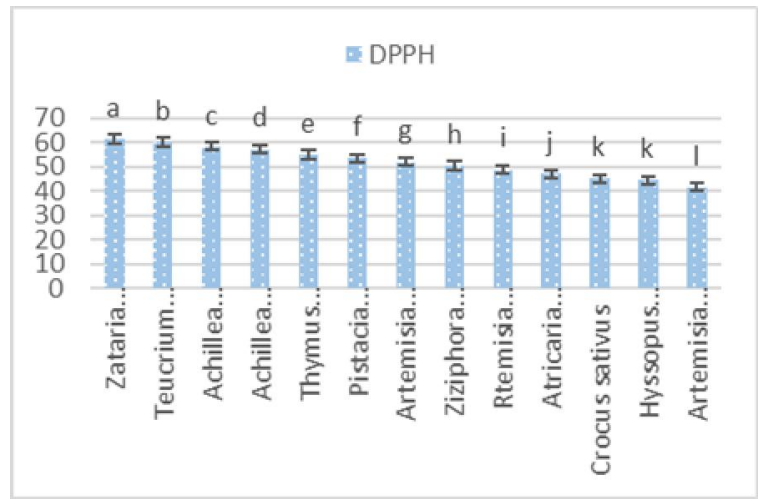

B

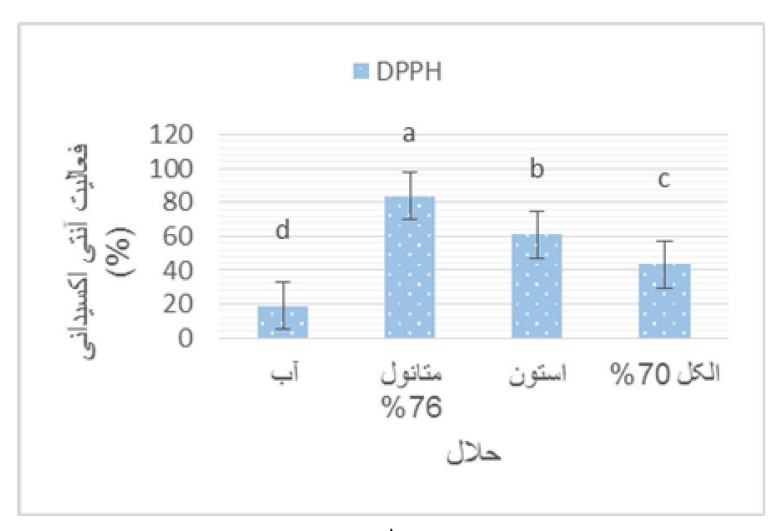

A

$$
\text { شكل 0-A ميزان فعاليت آنتى اكسيدانى حاصل از عصارههاى مختلف، B: ميزان فعاليت آنتى اكسيدانى گياهان مختلف. }
$$

Fig. 5. A: The amount of antioxidant activity caused by various solvent, B: The antioxidant activity of different plants. 


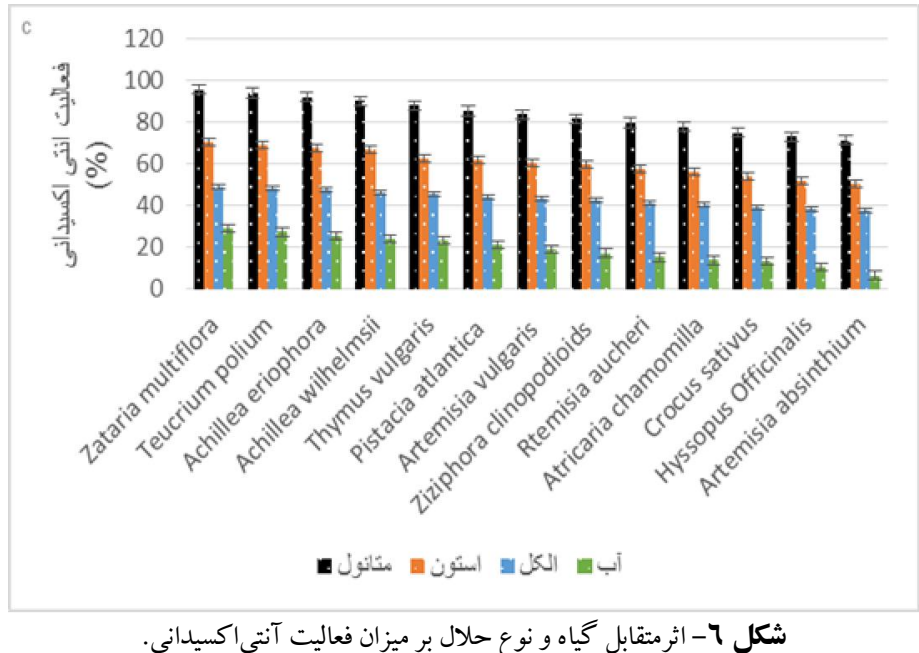

Fig. 6. Interaction between the plant and the type of solvent on the antioxidant activity.

بيشتر در كياهـان دارويى با مقـادير مختلف يافت مسىشوند. حسدود

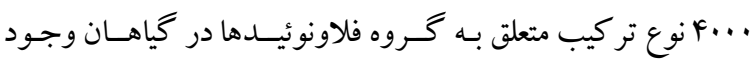

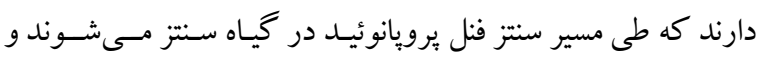

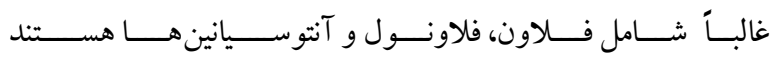
Morello et al., 2005; Siriamornpus \& Suttajit, ) . (2010

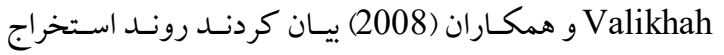
تر كيبات فنلى فاكتورى مهـم در تعيين ويز گیىهاى آنتسى اكسـيدانى

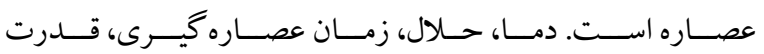

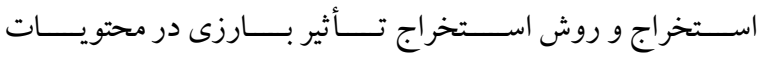
عصـاره خواهـــ كذاشت. اين تفاوتهـا بـه تمايـل ايسن تركيبـات

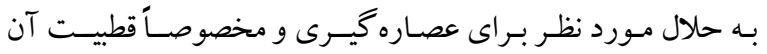

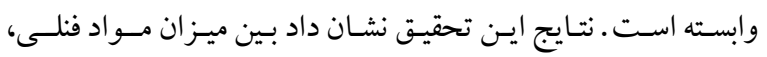

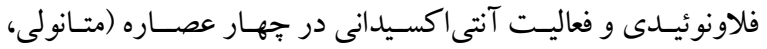

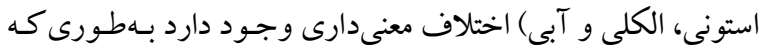

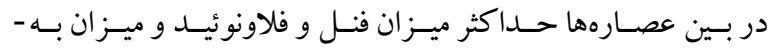

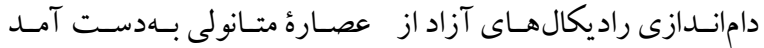

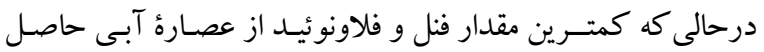

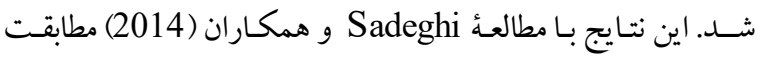
دارد. آنها در گزارشى بيان كردند ميزان تر كيبات فنلى فلاونوئيـدى

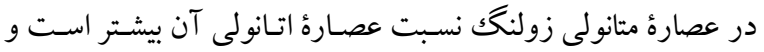

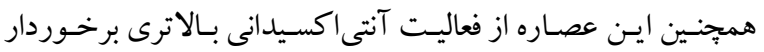

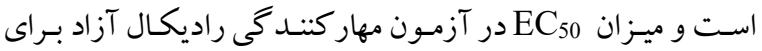
عصارة متانولى 19/99 بـر ميلى ليتر و بـراى آنتى اكسيدان سـنتزى
شامل مىشوند. استـخراج ايـن تر كيبـات بـه عواملـ متعـدى وابسته

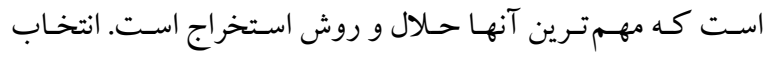

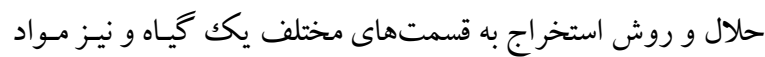

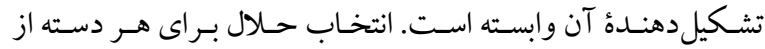

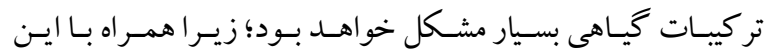

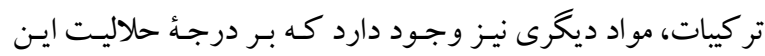

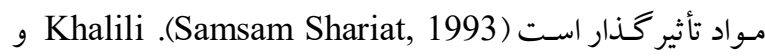
Ebrahimzadeh حضـور تر كيبات فنلى در آنها نسبت دادنـد. تر كيبـات فنلى شــامل

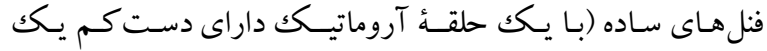

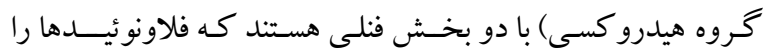

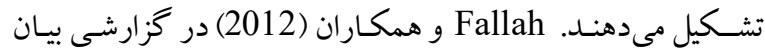

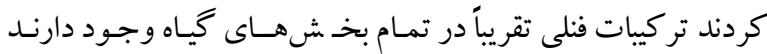

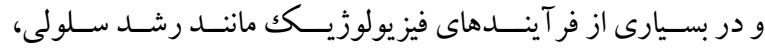

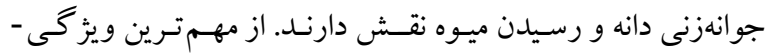

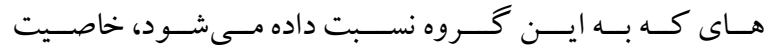

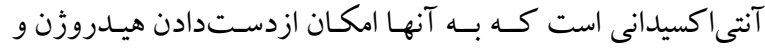

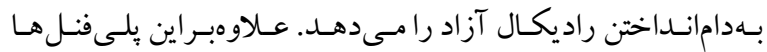

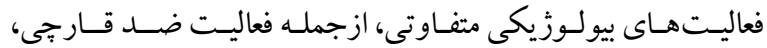

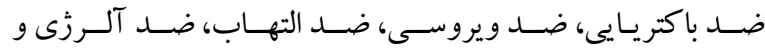

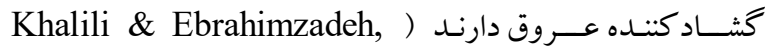
. (2015

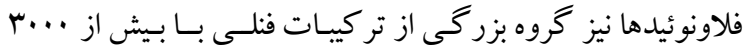

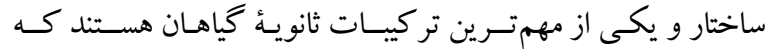


و فلاونوئيدى كل گياهان دارويى اسـت، بنـابراين، تفـاوت در ميزان

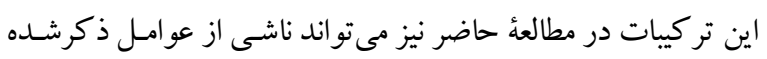

باشد.

اساس روش DPPH بر باية بىرنـك شـدن محلول DPPH اسـت كه بهوسيلة آنتى اكسيدانهاى موجـود در عصاره انجام مىشـود و

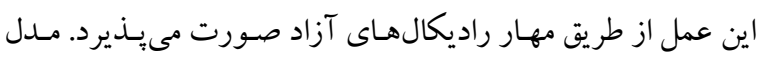

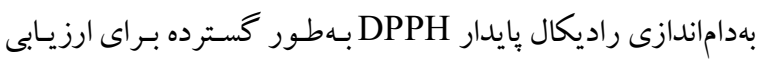

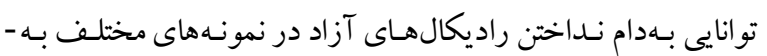
كار مىرود (Lee et al., 2003). در ايسن مطالهـه، عصارئ گيساه آويشن شيرازى نسبت به بقية گياهان فعاليت آنتى اكسيدانى بيشترى

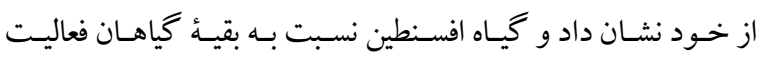
كمترى داشت؛ بنابراين، تفـاوت در فعاليـت آنتى اكسيدانى عصداره

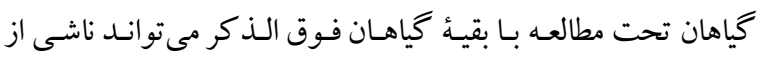

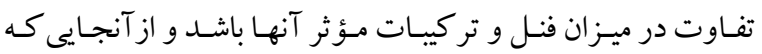

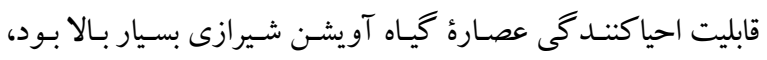

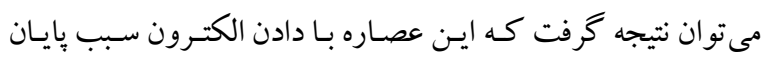
واكنش هاى زنجيرهاى مىشود (Lee et al., 2003). Karkevandi تر كيبـات فنلى تعـداد گـروههـاى هيدرو كسيل موجـود در محيط

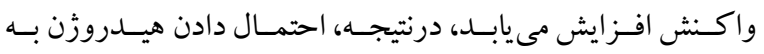

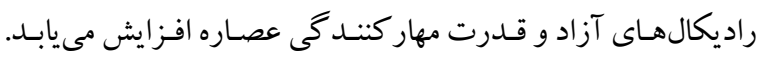

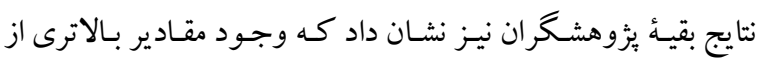

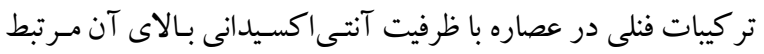

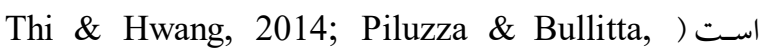

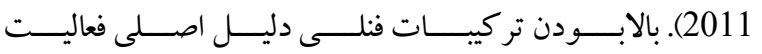

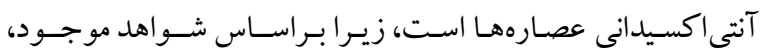
ارتبـاط مثتى بين تر كيبات فنلى و قدرت آنتى اكسـيدانى كياهـان وجسود دارد ( Mazandarani et al., 2011; Rahimi \& .(Ramezani, 2017

آل Arabshahi و Urooj

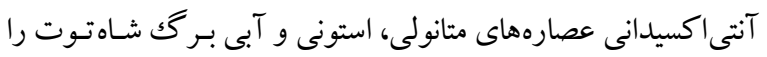

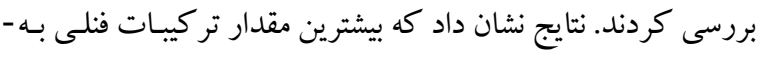

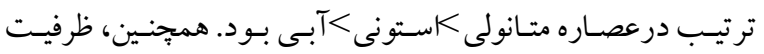

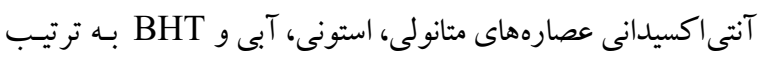

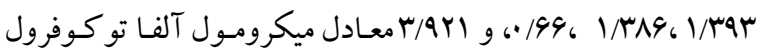

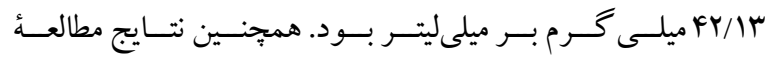

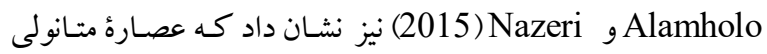
نسبت به عصاره اتانولى كارايى بيشترى دارد وعصارهُ متانولى گلى

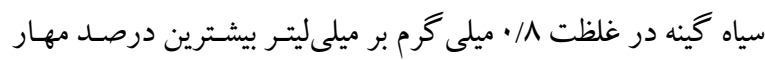

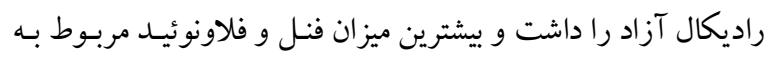

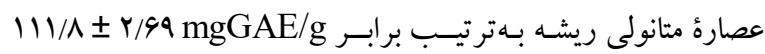
و

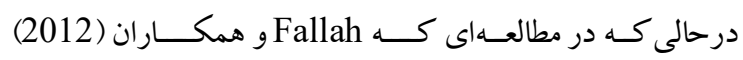

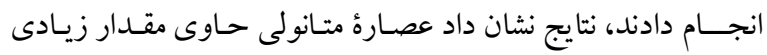

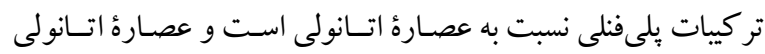

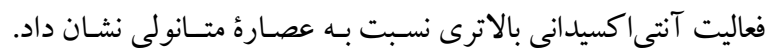

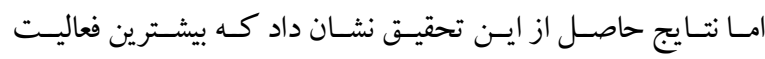

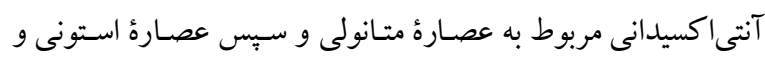

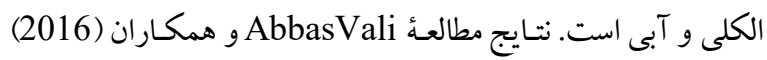
نشان داد كه مناسب ترين حلال استون است، درحسالى كه نتايج ايـن

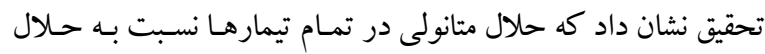

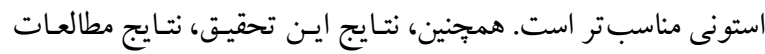

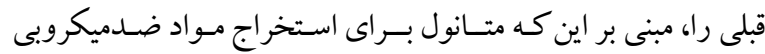

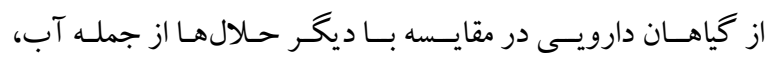

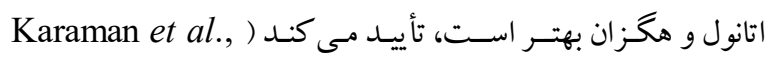
2003; Zgoda \& Porter, 2001

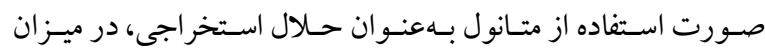

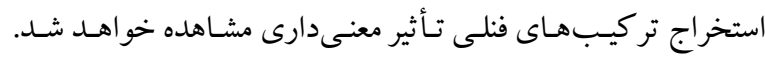

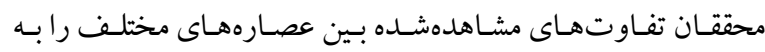
تفاوت در قطبيت حلالهاى بـه كاررفته مـرتبط مسىداننــ. استخر اج

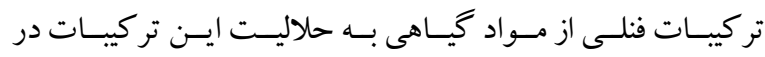

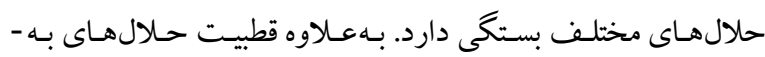

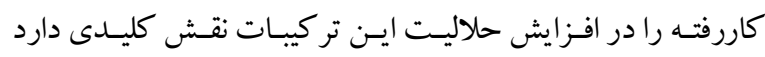
.(Hayouni et al., 2007) در ايـن مطالعه، حـداكثر ميزان فنل و فلاونوئيسد از كونـهُ آويشـن

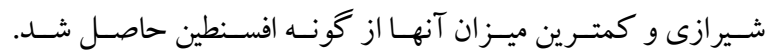
و Terronen

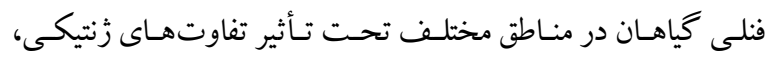

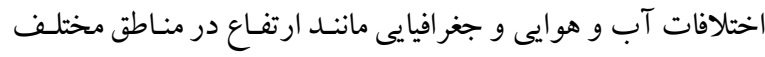

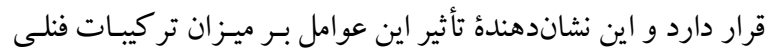


بين حلالهــاى مختلــف بـه كاررفتـه (استونى، متــانولى، اتـانولى و

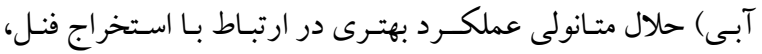
فلاونوئيد و ميزان مهار راديكالهاى آزاد داشت، درحسالى كـه حـلال آبى عملكرد ضسعيف ترى نسبت بـه بقيـهُ حلال هـا نشـان داد. در بـين

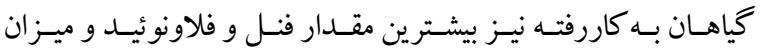
فعاليـت بـهدامانـدازى راديكالهــاى آزاد متعلـق بـهـ گيـاه آويشـن شيرازى بود، درحالى كه افسنطين كمترين مقدار را نشان داد.

\section{سياسگز ارى}

از همكـارى آزمايشـكاه تحقيقـات گياهــان دارويسى يثزوهشـكدة

$$
\text { زيستفناورى كشاورزى دانشگاه زابل تشكر و قدردانى مىشود. }
$$

\section{REFERENCES}

Abbas Vali, M., Esmaeili Kutmehr, M., Moshtaghi, H. and Escanderi, M.H. 2016. Evaluation of antibacterial extracts of acetone, ethanol and methanol leave four varieties of oleo in Iranian on the E. coli. - J. Food Microbio. 2: 67-77.

Ahmadi, F., Kadivar, M. and Shahedi, M. 2007. Antioxidant activity of Kelussia odoratissima Moza. in model and food systems. - J. Food Chem. 105: 57 64.

Alam Hollo, M. and Nazeri, S. 2015. Assessments of antioxidant and antibacterial activity of extracts alcoholic of flower and root Dendrostellera lesserti on some human pathogenic bacteria. - J. Med Sci. 21: 277-285.

Alamhulu, M. and Nazeri, S. 2015. Investigation antibacterial and antioxidant activities of alcoholic extracts of flower and root Dendrostellera lesserti on some human pathogenic bacteria. - Sci. J. Hamadan Univ. Med. Sci. 21: 277-285.

Arabshahi, D.S. and Urooj, A. 2006. Antioxidant properties of various solvent extracts of mulberry (Morus indica L.) leaves. - J. Food Chem. 102: 1233-1240.

Bahrami-Karkevandi, M., Moshtaghian, S.J., Mahzoni, P., Adibi, S. and Kazemi, S. 2011. The effects of hydroalcoholic extract of Artemisia aucheri on bleomycin induced pulmonary fibrosis in rats. - J. Med. Sci. 12: 33-40.

Betancourt, A.O. 2008. Analysis, extraction and recovery of poly-3- hydroxybutyrate in the biomass. - University of Quebec at Montreal Thesis, pp 45-55.

Burits, M. and Bucar, F. 2000. Antioxidant activity of Nigella sativa essential oil. - Phyto. Res. 14: 323-328.

Chang, Y.L., Kim, D.O., Lee, K.W., Lee, H.J., Lee, C.Y. 2002. Vitamin C equivalent antioxidant capacity (VCEAC) of phenolic phytochemicals. - J. of Agri. and Food Chem. 50: 3713-3717.

Choe, E. and Min, B.D. 2009. Mechanisms of antioxidants in the oxidation of food. - Rev. in Food Sci. and Food Safety 8: 345-358.
در گرم عصاره بود. اين نتايج با نتـايج تحقيـق حاضـر، از نظر وجـود ارتباط بين مقدار تر كيبات فنلى عصارهها بـا ظرفيـت آنتى اكسيدانى آنها، مطابقـت داشـت نتـايج Mirzaie و همكاران (2010) نشـان داد كه بهترين فعاليت آنتى اكسيدانى به درمنـه مربـوط بـود و الخـوى

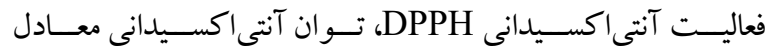
تروولكس كـه بـراسـاس ربـايش راديكـال نسـبتاً يايسـار سـبز آبسى است كه به يك محصول بىرنگك تبـديل مىشـود. شـدت كاهش رنگك نشاندهندهُ مقدار راديكال ABTS است كـه توسط آنتى اكسيدانها مهار شـده اسـت و ميـزان آن بـا دستـًاه طيـفسـنج نـورى انـازه گرفتـه مسىشـود (Re et al., 1998). ايـن روش را مسى تـوان بـر ای انـدازه كيــى آنتـى اكسـيدانهـاى محلـول در آب و تربى يا مو اد ناخالص و عصارههاى غـذايى در نظر كرفتـ. جـواب اين روش بر اساس عدد ترلكس مطرح مى شـود كـه برمبنـاى مقايســ

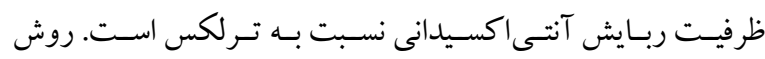

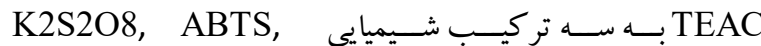
Mariken et al., 2003; ) وابسـته اســت TROLOX Gliszynska-Swiglo, 2006 و قدرت احيا كنند بيشترين به كمترين مقدار مربـوط بـه درمنـه، بابونسه و بومـادران بـود،

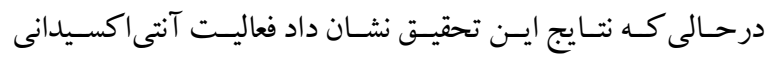

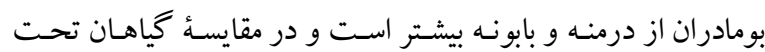

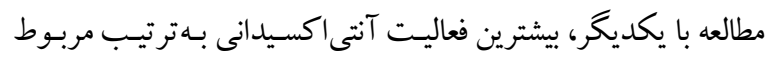

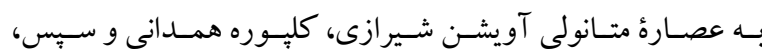

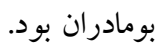
نتيجه كيرى

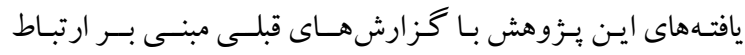
مستقيم اجزاى فنليـك بـا فعاليـت آنتى اكسـيدانى مطابقـت داشـت. بهطور كلى مى تـوان نتيجـه كرفـت كــه انتخــاب نــوع حسلال تـأثير زيـادى بــر ميـزان اسـتخر اج تر كيـبـهـاى فنلـى و فلاونوئيـدى دارد

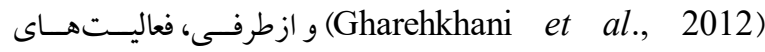
آنتى اكسـيدانى بـهـيـزان زيـادى تحــت تـأثير ماهيـت حسلال، زمـان استخراج و تعامل اين دو عامـل اسـت. بـاين حـال، قـدرت اسـتخراج حلال مهم تـرين فـاكتور مـؤثر بـر ظرفيـت آنتى اكسـيدانى محصـول است (Sadeghi et al., 2014). در اين مطالعه، بـا توجـه بـه نتـايج بـهدسـت آمــده از ارزيـابى اثـــ آنتى اكسـيدانى عصـارههـاى گياهـان مختلف استخراج شده با حلالهاى متفـاوت، مسى تـوان كفـت كـه از 
Ebrahimzadeh, M.A., Hosseinimehr, S J., Hamidinia, A. and Jafari, M. 2008. Antioxidant, and free radical scavenging activity of Feijoa sallowiana fruits peel and leaves. - Pharmacology 1: 7-14.

Fallah, H., Ksouri, R., Lucchessi, M.E., Abdelly, C.H. and Magné, C.H. 2012. Ultrasound-assisted extraction: effect of exraction time and solvent power onvthe levels of polyphenols and antioxidant activity of Mesembryanthemum edule L. Aizoaceae shoots. Tro. J. of Pharm. Res. 11: 243-249.

Gharehkhani, M., Ghorbani, M., Ebrahimzadeh, M.A., Gafari, S.M. and Sadeghimahonak, A.R. 2012. Comparison of different methods of extraction of phenolic compounds and flavonoids of Urtica dioica L. - Quarterly Sci. Res. of Med. and Aromatic Plants. 26: 389-405.

Gliszczynska-Swigło, A. 2006. Antioxidant activity of water soluble vitamins in the TEAC (trolox equivalent antioxidant capacity) and the FRAP (ferric reducing antioxidant power) assays. - J. Food Chem. 96: 131-136.

Hakkinen, S.H. and Torronen A.R. 2000. Content of flavonols and selected phenolic acids in Strawberries and Vaccinium species: influence of cultivar, cultivation site and technique. - Food Res. Int. 33: 517524.

Hayouni, A., Abedrabba, M., Bouix, M. and Hamdi, M. 2007. The effects of solvents and extraction method on the phenolic contents and biological activities in vitro of Tunisian Quercus coccifera and Juniperus phoenicea fruit extracts. - J. Food Chem. 105: 11261134.

Hwang, J.Y., Shue, Y.S. and Chang, H.M. 2001. Antioxidative activity of roasted and defatted peanut kernels. - Food Res. Int. 34: 639-647

Kamkar, A., Jebelli Javan, A., Asadi, F. and Kamalinejad, M. 2010. The antioxidative effect of Iranian Mentha pulegium extracts and essential oil in sunflower oil. - Food and Chem. Toxicol. 48: 17961800.

Karaman, I., Sahin, F. and Gullule, M. 2003. Antimicrobial activity of aqueous and methanol extraets of Juniperus oxycedrus. - J. Ethnopharmacol. 85: 231-235.

Khalili, M. and Ebrahimzadeh, M.A.A. 2015. Review on antioxidants and some of their common evaluation methods. - J. Mazandaran Univ. Med. Sci. 24: 188208.

Lee, K.W., Kim, Y.J., Kim, D.O., Lee, H.J. and Lee, C.Y. 2003. Major phenolics in apple and their contribution to the total antioxidant capacity. - J. Agric. Food Chem. 51: 651-20.

Lee, S.E., Hwang, H.J., Ha, J.S., Jeong, H.S. and Kim, J. H. 2003. Screening of medicinal plant extracts for antioxidant activity. - Life Sci. 73: 167-179.

Lutza, M., Henríquez, C. and Escobar, M. 2011. Chemical composition and antioxidant properties of mature and baby artichokes (Cynara scolymus), raw and cooked. - J. Food Compos. Anal. 24: 49-54.

Mahdavi, D.L., Deshpande, S.S. and Salunkhe, D.K. 1995. Food antioxidant. - Marcel Dekker Inc., New York, USA, 746 pp.
Mariken, J.T.J., Sebastiaan Dallinga, J., Hans-Peter, V., Guido, R.M.M. and Aalt, B. 2003. A critical appraisal of the use of the antioxidant capacity (TEAC) assay in defining optimal antioxidant structures. - Food Chem. 80: 409-414.

Mazandarani, M., Makri, S. and Bajian, G.R. 2011. Evaluation of phytochemical and antioxidant activity in different parts of Heracleum gorganicum Rech. f. in Golestan Province, north of Iran. - J. Plant Physio. 2: 381-388.

Mirzaei A, Akbartabartori M, Sadeghi H, Sharifi B. 2010. The evaluation of total phenol and antioxidant activity yarrow, wormwood and chamomile. - Journal of Armaghane Danesh. 15: 243-252.

Morello, J.R, Romero, M.P., Ramo, T. and Motilva, M. J. 2005. Evaluation of 1-phenylalanine ammonialyase activity and phenolic profile in olive drupe (Olea europaea) from fruit setting period to harvesting time. - Plant Sci. 168: 65-72.

Mour, A., Sruz, G.M., Franco, D. and Dominguez, J. 2001. Natural antioxidant from residual sources Food Chem. 72: 145-171.

Ordone, A.A.L., Gomez, J.D. and Vattuone, M.A. 2008. Antioxidant activities of Sechium edule Swartz extracts. - Food Chem. 97: 452-458.

Piluzza, G. and Bullitta, S. 2011. Correlations between phenolic content and antioxidant properties in twenty-four plant species of traditional ethnoveterinary use in the Mediterranean area. - Pharm. Biol. 49: 240-247.

Rahimi, M. and Ramezani, M. 2017. The effects of temperature on antioxidant activity, total phenolics and agronomic traits of two thyme species. - Nova Biologica Reperta. 4: 264-270.

Re, R., Pellegrini, N., Proteggente, A., Pannala, A., Yang, M. and Rice-Evans, C. 1998. Antioxidant activity applying an improved antiradical action decolonization assay. - PII S0891-5849, 00315-3

Sadeghi, A.R., Salmaneian, Sh., Jamsun, M. and Tabatabai Amid, B. 2014. Identify and measure the phenolic acids, radical scavenging activity and reducing power iron methanol extracts and ethanol Eryngium caucasicum. - J. Res. and Innovation in Food Sci. and Tech. 2: 193-204

Samsam Shariat, Sh. 1993. Extraction of effective components of herbal medicine, determination and evaluation methods. - Mani Press. Esfahan. Iran. pp: $12-13$.

Serrano, J., Goñi, I. and Saura-Calixto, F. 2006. Food antioxidant capacity determined by chemical methods may underestimate the physiological antioxidant capacity. - Food Rev. Int. 40: 15-21.

Shi, J., Nawaz, H., Pohorly, J. and Mittal, G. 2005. Extraction of polyphenolics from plant material for functional foods engineering and technology. - Food Rev. Int. 21: 1-12.

Siriamompus, S. and Suttajit, M. 2010. Microchemicals compounds and antioxidant activity of different morphological part of thai wildpurslane (Portulaca oleracea). - Weed Sci. 58: 182-188.

Thi, N.D. and Hwang, E.S. 2014. Bioactive compound contents and antioxidant activity in Aronia (Aronia 
melanocarpa) leaves collected at different growth stages. - Prev. Nutr. Food Sci. 19: 204-212.

Vilkha, K., Mawson, R., Simons, L. and Bates, D. 2008. Application and opportunities for untrasound assisted extraction in food industry; a review. - Innov. Food Sci. and Emer. Tech. 9: 161-169.

Zgoda, L.R. and Porter, J.R.A. 2001. Convenient microdultion method for screening natural products against bacteria and fungi - Pharmaceut. Biol. 39: 54221.

$$
* * * * *
$$

How to cite this article:

Mazarie, A., Mousavi-Nik, S.M. and Fahmideh, L. 2018. Assessments of phenolic, flavonoid and antioxidant activity of aqueous, alcoholic, methanol and acetone extracts of thirteen medicinal plants. - Nova Biologica Rep. 4: 299-309.

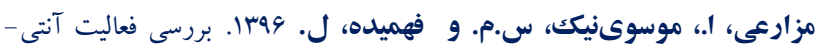
اكسيدانى، فلاونوئيدى و فنلى عصارههاى اتانولى، آبى، استونى و متانولى سولى سيزده كياه

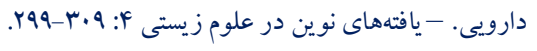

